\author{
УДК 323.2(355.1+355.2) \\ https://doi.org/10.34142/24130060.2019.17.1.07
}

\title{
АРМІЯ СУЧАСНОЇ ДЕРЖАВИ: ВИЗНАЧЕННЯ СТРАТЕГІЇ ДОСЛІДЖЕННЯ
}

\author{
І.Д. Денисенко, Ю.О. Тяпкіна \\ Харківський національний педагогічний університет імені Г.С. Сковороди
}

\begin{abstract}
Стаття містить спробу визначитися щуодо стратегї дослідження армї сучасної держави в контексті аналізу еволюиії інституційного підходу в західному соияіальнополітичному дискурсі.

Обтрунтовується, що перспективність иієї пропозищї базується на таких моментах, як: існування досить успішної практики розгляду армї як певного політичного інституту в сучасному науковому дискурсі; розробка нового (більш конструктивного) варіанту інтерпретації конщепту «політичний інститут»; формування в межах неоінституціоналізму базової дослідницької установки, «яка дозволяє розглядати колективні, організаційні та ментальні структури і процедури, а також індивідуальну поведінку з єдиних аналітичних позицій».
\end{abstract}

Ключові слова: армія, інститут, політичний інститут, інституціональна теорія, інституціоналізм, неоінституціоналізм.

\section{АРМИЯ СОВРЕМЕННОГО ГОСУДАРСТВА: ОПРЕДЕЛЕНИЕ СТРАТЕГИИ ИССЛЕДОВАНИЯ}

\section{И.Д. Денисенко, Ю.О. Тяпкина}

Статья содержит попьтку определиться относительно стратегии исследования армии современного государства в контексте анализа эволючии институционального подхода в западном социально-политическом дискурсе. Обосновывается, что перспективность данного предложения базируется на таких моментах, как: существование достаточно успешной практики рассмотрения армии как определенного политического института в современном научном дискурсе; разработка нового (более конструктивного) варианта интерпретаџии концепта «политический институт»; формирование в рамках неоинституционализма базовой исследовательской установки, «которая позволяет рассматривать коллективные, организационные и ментальные структуры и процедуры, а также индивидуальное поведение с единых аналитических позицииц̆».

Ключевые слова: армия, институт, политический институт, институциональная теория, институционализм, неонституционализм.

(C) І.Д. Денисенко, Ю.О. Тяпкіна, 2019 


\section{ARMY OF THE MODERN STATE: DETERMINATION OF RESEARCH STRATEGY}

\section{Denysenko, Y. Tiapkina}

The article contains an attempt to determine the strategy of research of the army of the modern state in the context of analyzing the evolution of the institutional approach in Western social and political discourse.

The emphasis is on the content of changes that allowed institutional theory not only to transform into a non-institutional, but also to become the leading methodological basis for modern political research at all levels.

It is about a change: in the categorical and conceptual apparatus of the research (for example, the new interpretation of the content of the main concepts (from the institute to the rational choice and the introduction into the scientific circulation of the concepts institutional space, institutional practice, rules of the game and etc.); principles of research; levels of research (identification of institutional, organizational and individual levels); subject field of research (first of all, introduction of individual behavior of actors into it); methods and procedures of analyze (use of tools of rational choice theory, structural and functional analysis, behavioral approach).

It is substantiated that the perspective of using the main provisions of this approach to analyze the problem field of the modern army is based on such moments as: the existence of a fairly successful practice of considering the army as a specific political institution in modern scientific discourse; development of a new (more constructive) version of the interpretation of the concept of political institution; the formation, within the framework of neoinstitutionalism, of a basic research set, which allows considering collective, organizational, and mental structures and procedures, as well as individual behavior from a unified analytical position.

Key words: army, institute, political institution, institutional theory, institutionalism, neoinstitutionalism.

Постановка проблеми. У сучасних умовах існування світової системи держав, що характеризуються, насамперед новим рівнем загострення міжцивілізаційних протиріч та глобальних проблем, невпинно зростає значущість військового потенціалу (армії) кожної країни в забезпеченні їі захисту та безпеки. Саме це і обумовлює актуальність пошуку адекватних засад дослідження проблем формування та функціонування армій сучасного світу.

Аналіз актуальних досліджень. Проблемне поле армії в сучасному соціально-політичному дискурсі представлено трьома великими групами досліджень. Першу групу складають результати аналізу місця і ролі армії в контексті еволюції війни як соціального феномену (від М. Кревельда до В. Горбуліна); другу - вивчення взаємодії суспільства i армії в межах становлення і розвитку людської цивілізації (Е. Тоффлера до М. Требіна); 
третю - інтерпретації армії як соціального інституту (від П. Сорокіна до Е. Афоніна).

Звертає на себе увагу факт домінування в цих дослідженнях у якості їх методологічних засад провідних положень структурно-функціонального та системного підходів.

Однак, з огляду на високу оцінку евристичного потенціалу так званого «неоінституціоналізму» (модернізованого варіанту традиційного інституційного / інституціонального підходу), яка присутня в сучасному науковому дискурсі (Байме, 2008, с. 140; Гудин и Клингеманн ред., 1999, с. 43), здається доцільним звернутися до основних положень цієї теорії для підвищення рівня інтерпретації проблемного поля сучасної армії.

Виходячи із вищезазначеного, мета статті - визначитися щодо стратегії дослідження армії сучасної держави у контексті аналізу еволюції інституціонального підходу у західному соціально-політичному дискурсі.

Виклад основного матеріалу. Інституційна проблематика досить широко представлена в сучасній західній соціально-політичній науці. Умовно всю сукупність публікацій, які іiі презентують, можна розділити на три великі групи, що містять результати досліджень авторів, які спеціалізуються на:

розгляді різних соціальних інститутів сучасного суспільства (Дж. Александер, Е. Гідденс, Р. Дарендорф, С. Гантінгтон та ін.);

вивченні особливостей виникнення, розвитку і функціонування саме політичних інститутів соціуму (С. Верба, Г. Алмонд, М. Дюверже, Ч. Міллс, С. Оффе, М. Террі, Ю. Хабермас, Р. Фодес);

аналізі специфіки формування i еволюції в системі соціальнополітичного знання інституціонального підходу (Дж. Марч, П. Мер, Д. Норт, П. Олсен, Б. Петерс, Ф. Шарп та ін.).

Слід зауважити, що у вітчизняному науковому дискурсі найбільш широко представлені дослідження, які можна віднести до перших двох груп публікацій. 
Так, проблемне поле соціальних інститутів $є$ предметом вивчення Л. Корецької, Т. Крижановської, В. Матусевич, О. Полисаєва, М. Хилька та інших, політичних - О. Воронянського, Р. Демчишака, Д. Зубрицької, М. Кармазіної, В. Козьми, М. Михальченка, П. Петрова, А. Романюка та інших.

Що стосується третьої групи досліджень, то результати наукових розвідок у напрямку уточнення змісту, евристичного потенціалу та перспектив розвитку інституційної теорії тільки стали з'являтися у вітчизняному соціально-політичному дискурсі (Бульдович, 2017; Демчишак, 2015; Колодій, 2011; Петров, 2017).

У сучасній системі соціально-політичних знань формуванню так званої «інституціональної» теорії передувала ціла низка досліджень, в яких містився досить всебічний аналіз інститутів суспільства (в тому числі і політичних), але в межах розробки різних теоретичних конструкцій, що інтерпретували ті чи інші елементи соціальної реальності.

Одним 3 перших в цьому напрямку працював французький філософ i соціолог Огюст Конт. У контексті формування його нової концепції розвитку суспільства (позитивістської), знання про останнє пропонувалося представляти у двох розділах - соціальній статиці і соціальній динаміці. Соціальна статика розглядає суспільство в стані стійкої рівноваги всіх його соціальних елементів, соціальна динаміка - в процесі їх постійного розвитку. При цьому в теорії французького дослідника соціальна статика була пов'язана 3 формуванням і проявом такої частини суспільного цілого - як порядок, а соціальна динаміка - як прогрес.

У контексті вищевикладеного О. Конт запропонував розглядати соціальні інститути (сімейні, політичні, військові, релігійні, економічні) як провідні елементи суспільного життя, тобто, як певні складові, що одночасно підкоряються законам соціальної статики і динаміки i, відповідно, що відповідають у остаточному варіанті за порядок в суспільстві і його прогрес. 
Згідно з результатами теоретичних досліджень англійського вченого Герберта Спенсера, соціальні інститути - це диференційовані і спеціалізовані «органи», які організовують існування спільного життя членів суспільства («соціального організму»). Спочатку дослідник запропонував розрізняти три основних типи інститутів: інститути, що продовжують рід (шлюб і сім'я); розподільні (або економічні) інститути і інститути, які регулюють відносини в суспільстві (релігія, політичні системи) (Беккер и Босков, 1961, с. 24-25).

Пізніше, в контексті уточнення положень своєї теорії еволюції, вчений запропонував виділяти вже п'ять груп інститутів, а саме: домашні (сім'я, шлюб); обрядові або церемоніальні (звичаї, етикет, традиції); політичні (держава, армія, поліція); церковні (церква, секта, монастир); професійні та промислові (цех, професійні спілки, фабрики). Виникнення кожної з груп інститутів, згідно з дослідженнями англійського вченого, безпосередньо пов’язане з процесом так званої «надорганічної» еволюції суспільства. Наприклад, у контексті міркувань Г. Спенсера, поява інститутів політичного типу детермінована необхідністю врегулювання всезростаючої в суспільстві кількості конфліктів між різними групами. Саме потреби суспільства в обороні або завоюванні і освоєнні чужих територій i ресурсів здатні найбільше гуртувати і дисциплінувати його членів, змушують утворювати державу, арміі і інші інститути, що забезпечують інтеграцію, порядок i безпеку для його представників.

При цьому дослідник акцентував увагу на тому, що всі інститути суспільства складають єдине ціле, функціонування кожного 3 них залежить від всіх інших і від чіткого поділу сфер впливу і відповідальності. У будьякому суспільстві $\epsilon$ певний рівень узгодженості в діяльності основних інститутів, в іншому випадку починається регрес або розпад «соціального організму». Кожен соціальний інститут покликаний задовольняти певну суспільну потребу і не підміняти інші інститути.

На позиціях такого інституційно-функціонального розуміння умов існування суспільства стояв і німецький політолог Макс Вебер. Згідно до 
результатів його досліджень, соціальні інститути - це «складні мережі соціальних відносин і інтересів або функції, пов'язані з якоюсь структурою покори, обов'язки або, якщо використовувати термінологію Вебера, законності» (Беккер и Босков, 1961, с. 42). При цьому, в межах розробки його концепції легітимного панування обгрунтовується, що і діяльність таких структур, i здійснення їх взаємовпливу один на одного відбуваються виключно на певних умовах організації і здійснення політичного управління (традиційного, харизматичного і раціонального).

Більш всебічно зв’язок між провідними соціальними інститутами суспільства був розкритий в дослідженнях американського соціолога i політолога Ч. Міллса (в контексті формування його концепції правлячої еліти).

Для американського дослідника основоположним моментом для взаємодії таких соціальних інститутів як економіка, політика і армія виступає потреба в забезпеченні й підтримці панування певної соціальної групи пануючої еліти. У контексті досягнення зазначеної мети армія призвана забезпечувати:

«збереження недоторканності державних кордонів, забезпечення державного суверенітету країни; сприяння розвитку й реалізації соціальноекономічного потенціалу держави; підтримку політичної стабільності в суспільстві; здійснення процесу нормативної соціалізації громадян держави; формування лояльної щодо політики, яку здійснює держава, громадської думки» (Тяпкіна, 2018, с. 183).

Слід підкреслити, що у сучасному соціально-політичному дискурсі загальноприйнято вважати засновником теорії інституціоналізму французького дослідника Mоріса Opiy. Вважається, що саме він першим сформував доволі логічну систему положень про виникнення інститутів, їх структуру та види, специфіку розвитку та умови ефективного функціонування і взаємозв'язку у межах окремого суспільства (Кирилюк, 2009, c. 155). 
У контексті досліджень М. Оріу, сучасне суспільство - це результат взаємодії різних інститутів (від корпорації до держави). При цьому інститут пропонується розглядати як ідею справи або підприємництва, яка здійснюється правовими засобами, тобто, як різні юридичні організації, що мають багато спільних рис: організуючу і спрямовуючу ідею; нормативно упорядковане внутрішнє життя; автономність; авторитарну структуру i тривалість існування (Кирилюк, 2009, с. 155).

За цих умов всі інститути пропонується розподіляти на дві групи: інститути так званого «корпоративного типу» (від держави до торговельних товариств), для яких характерно функціонування виключно у форматі соціальних колективів; і інститути так званого «речового типу» (сукупності правових норм), існування яких не структуровано простором певної організації й здатне застосовуватися в межах будь-яких об’єднань.

У подальшому, завдяки результатам досліджень Е. Баркера, Дж. Брюса В. Вільсона, Г. Ласкі, Г. Фінера, К. Фрідріха та іншим до середини ХХ ст., інституціональна теорія (інституціоналізм) зайняла одне із провідних місць у політичній науці. Вважається, що це відбувалося завдяки інструментарію інституціоналізму (зокрема, активному застосуванню трьох головних методів дослідження - описово-індуктивного, формально-легального та історикокомпаративістського) та його провідної дослідницької стратегії - орієнтація на об’єднання емпіричних досліджень політики 3 аналізом політичних цінностей.

Згідно до тверджень Федора Кирилюка, «інституціональний підхід дає змогу досліджувати причини виникнення, розвитку й становлення політичних інститутів та політичних цінностей, які вони виражають» (Кирилюк, 2009, с.24).

3 часом, інституціональний підхід «втратив довіру» (за словами Клауса фон Байме) серед політознавців післявоєнного періоду щодо свого пізнавального потенціалу. «Бо був, - стверджує К. фон Байме, - не взмозі відповісти на заклики біхевіоралістів досліджувати політичну поведінку, 
оскільки переважно займався висхідними функціями держави, такими як парламент, уряд, управління, правозахист і почасти дуже інституціонально підходив також і до політичних форм організації суспільної сфери» (2008, c. 128).

У контексті реакції на критику щодо пізнавального потенціалу традиційного інституціоналізму у західній політичній науці на початку 80-х років XX ст. його провідні принципи та стратегії дослідження в публікаціях його прибічників зазнали суттєвих змін та трансформацій.

Зокрема, йдеться про зміни щодо: категоріально-понятійного апарату дослідження (наприклад, нова інтерпретація змісту основних концептів (від «інституту» до «раціонального вибору» і введення в науковий обіг понять «інституційний простір», «інституціональна практика», «правила гри» i т. ін.); принципів дослідження; рівнів дослідження (виділення інституційного, організаційного та індивідуального рівнів); предметного поля дослідження (перш за все, через залучання до нього проблем індивідуальної поведінки політичних акторів); методів і процедури аналізу (використання інструментарію теорії раціонального вибору, структурно-функціонального аналізу, поведінкового підходу).

Так, завдяки науковим розвідкам А. Лейпхарта, Дж. Марча, П. Мера, Д. Найта, Д. Норта, Й. Олсена, Е. Острома, Р. Патнема, Т. Скокпол, С. Стейнмо, К. Телені, К. Шепслі, П. Холла, та інших був сформований теоретико-методологічний потенціал так званого «нового інституціоналізму» («неоінституалізму»), який пропонується презентувати через такі положення: життя сучасного суспільства характеризується діяльністю сукупності різних політичних інститутів (від «інституту інститутів»- держави до «виборів»); всі політичні інститути на всіх рівнях свого функціонування - повноправні політичні актори, що мають власні специфічні потреби та інтереси; кожен 3 інститутів (у певній мірі) здійснює визначальний вплив на індивідуальну поведінку, встановлюючи межі індивідуального вибору через формування ціннісних пріоритетів; інститути є провідною детермінантою, що визначає 
результати політики у контексті допомоги політичним акторам усвідомлювати свої цілі (Гудин и Клингеманн ред., 1999, с. 313-314).

Слід зазначити, що у межах нового варіанта інституціональної теорії, який презентований кількома напрямами (від «економічного інституціоналізму» до «соціологічного інституціоналізму»), зміст концепту «політичні інститути» інтерпретується доволі широко, виступаючи певним результатом систематизації та узгодження провідних визначень щодо цього поняття, запропонованих представниками як традиційного, так й нового інституціоналізму. При цьому обгрунтовується, що за умов такого розуміння цих організаційних структур, їх функціональний потенціал не обмежується інструментальною роллю щодо реалізації державної влади. Для політичних інститутів характерно: здійснення допомоги щодо вирішення проблем, які виникають при колективній взаємодії суб'єктів політики різних рівнів; контроль, сприяння та змушування до виконання встановлених, загальноприйнятих норм та правил в суспільстві; мобілізація всіх ресурсів та зусиль на досягнення певних політичних цілей (Terry, 1990, p. 213).

За такого контексту можна погодитися із твердженнями цілої низки як західних, так й вітчизняних фахівців, що «неоінституціоналізм найбільш доречно визначати як метод, певний набір аналітичних принципів, який дозволяє продуктивно вивчати найбільш важливі суспільно-політичні явища і процеси як мікро-, так і макрорівня, а головне - обгрунтувати генетичний зв’язок між ними» (Бульдович, 2017, с. 23-24).

Висновки i перспективи подальших досліджень. Виходячи 3 вищевикладеного, можна обгрунтовано припустити, що найбільш ефективною стратегією дослідження проблемного поля армії сучасної держави в соціально-політичному дискурсі $\epsilon$ пропозиція розгляду його 3 позиції основних положень неоінституціоналізму. Перспективність даної пропозиції базується на наступних моментах: 
по-перше, існування досить успішної практики розгляду армії як певного політичного інституту в сучасному науковому дискурсі (наприклад, в дослідженнях Г. Спенсера і Ч. Міллса);

по-друге, розробка нового комплексного варіанту інтерпретації концепту «політичний інститут» (від «організованих структур» до «сукупності норм і правил», які їх структурують і організовують), який дозволяє розглядати армію одночасно і як певну організацію, яка виконує конкретні функції щодо досягнення державних цілей, і як систему, яка здійснює діяльність у напрямку задоволення своїх специфічних цілей в контексті активної взаємодії з іншими системними утвореннями соціальнополітичної реальності;

по-третє, формування в межах неоінстітуціоналізму базової дослідницької установки, «що дозволяє розглядати колективні організаційні та ментальні структури і процедури, а також індивідуальну поведінку 3 єдиних аналітичних позицій» (Беккер и Босков, 1961, с. 24). Екстраполюючи цей момент на процес дослідження проблемного поля сучасної армії, отримуємо чітку дослідницьку стратегію: визначаємо армію як політичний інститут; визначаємо рівні організації його існування; визначаємо провідні компоненти кожного рівня; обгрунтовуємо сукупність взаємозв'язків між ними; розробляємо підстави (надалі механізми) постійного відтворення цієї структури та умов змін та трансформацій.

\section{ЛІТЕРАТУРА}

1. Байме, К., 2008. Політичні теорї сучасності. Переклад з німецької М. Култаєвої та М. Бойченка. Київ: Стилос.

2. Беккер, Г. и Босков, А., 1961. Современная соичологическая теория в ее преемственности и изменении. Перевод с английского В.М. Карзинкина и Ю.В. Семенова. Москва: Издательство иностранной литературы.

3. Бульдович, П.В., 2017. Проблема ідентифікації неоінституціонального підходу в сучасній політичній науці. Політичне життя, 3, с. 21-25.

4. Демчишак, Р., 2015. Наукові підходи до розуміння сутності поняття «політичний інститут». Українська національна ідея: реалії та перспективи розвитку : Збірник наукових праць, 27, с. 9-14.

5. Кирилюк, Ф.М. 2009. Новітня політологія: навчальний посібник для студ. вищих навчальних закладів. Київ: Центр учбової літератури. 
6. Колодій, А., 2011. Неоінституціоналізм та його пізнавальні можливості в політичних дослідженнях. Вісник Львівського університету. Серія філософсько-політологічні cmydii, 1, с. 129-139.

7. Петров, П. Г., 2017. Політичні інститути: узагальнення змісту підходів до визначення поняття. Науково-теоретичний альманах «Грані», 20(9), с. 64-71.

8. Гудин, Р. и Клингеманн, Х-Д. ред., 1999. Политическая наука: новые направления. Перевод с английского М.М. Гурвица, А.Л. Демчука. Москва: Вече.

9. Тяпкіна, Ю.О., 2018. Проблемне поле армії в контексті теретичної спадщини Ч. Міллса. Сучасне суспільство: політичні науки, сочіологічні науки, культурологічні науки. Збірник наукових праџь, 1(15), с. 177-185.

10. Terry, M. Moe, 1990. Political Institutions: The Neglected Side of the Story. Journal of Law, Economics, \& Organization, [online] 6, pp. 213-253. Available at: https://filespoliticalscience-stanford-edu.s3.amazonaws.com/s3fs-

ublic/politicalinstitutions_neglectedside.pdf [Accessed 25 January 2019]

\section{Інформація про авторів}

Денисенко Ірина Дмитрівна - доктор філософських наук, професор, декан факультету психології і соціології Харківського національного педагогічного університету імені Г.С. Сковороди; e-mail: irdden@gmail.com; ORCID: http://orcid.org/0000-0002-1956-571X.

Тяпкіна Юлія Олегівна - аспірантка кафедри політології, соціології і культурології Харківського національного педагогічного університету імені Г.С. Сковороди; e-mail: yuliaolegovnat@gmail.com; ORCID: http://orcid.org/0000-0002-3240-3555.

Стаття надійшла до редакції: 30.01.2019 р. Прийнята до друку: 07.02.2019 р. 